\title{
International Standards For Exporting Firms: Evidence From China
}

\author{
Ying Sun, China JiLiang University, China
}

Wenjing Ouyang, University of the Pacific, USA

\begin{abstract}
The existing literature provides mixed evidence of the impact of ISO 9000 international standards on country level export growth. Since it is costly to adopt the international standards, it is important to understand how these standards increase exports at the firm level. This paper examines the effect of ISO 9000 standards on firm-level export growth in China, which of all countries has the highest number of firms adopting ISO 9000 standards. With the assortative matching methodology, we first examine the factors related to the choice of applying for the certification. After controlling for this endogeneity issue, our results show that obtaining ISO 9000 standards significantly increases firm exports. Furthermore, we find low-tech firms and non-stateowned enterprises are more likely to benefit from adopting the standards. Overall, our study provides important guidelines for firms applying for the international quality standards.
\end{abstract}

Keywords: ISO 9000 Standards; Exports Growth; Chinese Economy

\section{INTRODUCTION}

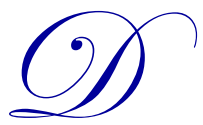

eveloped countries often resist exports from developing countries if the exports do not meet their country quality standards. In order to increase exports to developed countries, more and more enterprises choose to adopt international standards to reduce consumers' uncertainty about the quality of products and thus increase selling in the market (Uzumeri, 1997). Till now, the most important and widespread voluntary standards is the ISO (International Standard Organization) 9001:2000 series. "The standards provide guidance and tools for companies and organizations who want to ensure that their products and services consistently meet customer's requirements, and that quality is consistently improved." The ISO 9000 family covers various aspects of quality management. Among them, ISO 9001 sets out the requirements of a quality management system. $^{2}$ As of December 2011, the total number of ISO 9001 certificates reaches 1,111,698 across 178 countries around the world. ${ }^{3}$

Country level studies about the impact of adopting ISO 9000 standards on exports provide mixed results. Some argue adoption of ISO 9000 standards significantly increases exports by improving internal management quality and reducing information asymmetry in international trading (Swann, Temple, and Shurmer, 1996; Rao, Ragu-Nathan, and Solis, 1997; Blind, 2001; Grajek, 2004). Critiques on these studies argue the results are driven by omitted variables and only hold in certain countries (Temple and Urga, 1997; Blind and Jungmittag, 2002; Clougherty and Grajek, 2008).

Since it is costly to obtain the ISO 9000 standards (Dissanayaka, Kumarsawamy, Karim, and Marosszeky, 2001; Lo, Yeung, and Cheng, 2009), it is critical to understand the mechanism through which the standards bring value to an individual firm. However, studies on firm-level exports and ISO 9000 standards provide limited evidence. Masakure, Henson, and Cranfield (2009) and Martincus, Castresana, and Castagnino (2010) report

\footnotetext{
${ }^{1}$ Source: ISO website. http://www.iso.org/iso/home/standards/management-standards/iso_9000.htm

${ }^{2}$ ISO 9000 family includes 3 other standards. ISO 9000 covers the basic concepts and language, ISO 9004 focuses on how to make a quality management system more efficient and effective, and ISO 19011 sets out guidance on internal and external audits of quality management systems.

${ }^{3}$ Data source: “The ISO Survey of Management System Standard Certifications (1993-2011)" published on the ISO website.
} 
adopting ISO 9000 standards increases growth in exports in Pakistan and Argentina, respectively. Since these studies use the data covering only several of the exporting industries, their evidence is not general to entrepreneurs as to whether it is practical for their firms to adopt the quality standards. Chen, Wilson, and Ostuki (2008) use the survey data from World Bank Technical Barriers to Trade Survey (2004) and also find quality standards significantly increase exports. However, due to the limitation of survey data, it is not clear whether their results are driven by measurement error. ${ }^{4}$

This paper aims to provide new evidence of the impact of ISO 9000 standards on firm-level exports. In particular, we study the exports from Chinese firms. From 2009, China has become the top exporting country in the world. In 2011, China's export volume has reached 1,898.6 billion dollars. ${ }^{5}$ In addition, its average growth rate during the period from 1978 to 2011 is $17.2 \%$, which has significantly surpassed that of the overall Chinese economy (Rodrik, 2006). Therefore, to examine factors increasing Chinese exports is a significant and interesting topic. In addition, the number of ISO 9000 certificates has been increasing since the 1990's. In 2011, China possesses the most number of ISO 9000 standards in the world, taking more than $40 \%$ of that by the top 10 countries. ${ }^{6}$ To our knowledge, this study is the first to examine whether adoption of ISO 9000 standards increases Chinese firm exports.

To control for the endogeniety of adopting the quality standards at the first place, we use the propensity score matching methodology to pair certified firms with noncertified counterparts. Then, we examine the average effect of the standards on certified firms with difference-in-differences. Our results show, on average, ISO 9000 certification increases firm export growth by more than RMB 1.3 million (around \$200,000). This observation is consistent with the literature that to obtain international standards increases the products' competitiveness in the international arena (Swann et al., 1996; Grajek, 2004).

Since each industry has its own characteristics, we further ask whether the above mentioned positive effect varies across industries. We find low-tech firms benefit more from the certification than high-tech firms do. Unlike high-tech firms who have alternative signaling channels (e.g. patent grants), low-tech firms are harder to distinguish themselves from competitors. Certification by the quality standards is therefore more salient for low-tech firms to stand out in international competition.

Chinese state-owned enterprises (SOE) play a significant role in Chinese economy. However, studies find the reform in SOEs is not deep enough to get them as competitive as non-SOEs (Mak, 2008; Pyke, Farley, and Robb, 2002). Our sample shows that a higher percentage of SOEs obtain ISO 9000 certification than non-SOEs. We therefore examine whether the adoption of the quality standards is for export growth or because of bureaucracy. Our results show adoption of ISO 9000 standards does not significantly increase exports in SOEs, suggesting these firms may obtain the quality certification just to comply with the government.

Our study contributes to the literature in the following aspects. First, it provides new firm-level evidence of the impact of adopting ISO 9000 standards to export growth. Most of previous studies on quality standards examine country-level exports and provide mixed results (Swann et al., 1996; Grajek, 2004; Clougherty and Grajek, 2008). Although Masakure et al. (2009) and Martincus et al. (2010) study firm-level exports, they do not differentiate the effects among firms in different industries and with diverse ownership structure. Our study provides more meaningful and practical guidelines to firms' strategy in applying for the costly quality standards.

Second, our study provides new evidence regarding factors affecting Chinese exports. Existing studies find foreign direct investment (Xu and $\mathrm{Lu}, 2009$ ), exchange rate and worldwide demand (Yue and Hua, 2002), as well as foreign enterprises in the processing trade (Amiti and Freund, 2010) etc. play a role in Chinese export growth. On top of these findings, our study reports a positive impact of ISO 9000 standards on Chinese exports. Given the fact

\footnotetext{
${ }^{4}$ In their study, the dummy variable -quality standards - equals 1 when respondents answer 'Yes' to the question 'Have quality/performance standards impacted your ability to export product?', and 0 when they answer 'No'. However, it is not clear whether the dummy variable measures the adoption of quality standards or respondents' belief that quality standards matter for exports.

${ }^{5}$ Data source: China External Economics Statistical Yearbook 2012, China Statistics Press.

${ }^{6}$ The specific number of ISO 9000 certificates obtained by Chinese firms since 1990's is reported in Appendix A. In 2011, the top 10 countries and their possessed number of ISO 9000 certificates are reported in Appendix B.
} 
that China currently possesses the largest number of ISO 9000 certificates, this study demonstrates the benefit of obtaining the certificates.

Last but not the least, this paper provides important policy implication for Chinese SOEs. Some studies show that SOEs have significantly increased the total factor productivity during the period of China's enterprise reform (Jefferson, Rawski, and Zhang, 1994). While others argue there are still mounting problems within SOEs, which leads to significant financial losses and increased reliance on government subsidies (Bai, Li, and Wang, 1997). Our finding that SOEs may obtain ISO 9000 just to comply with the government suggests that the reform in these firms is not thorough yet.

The remainder of the study includes the following sections. Section 2 reviews the literature and introduces related studies. Section 3 explains our research models and variable definitions. Section 4 discusses the data and sample collection process. Section 5 reports empirical test results. And Section 6 concludes.

\section{LITERATURE REVIEW}

Existing studies find a positive relation between adoption of ISO 9000 standards and country level exports. Rao et al. (1997) find ISO 9000 certified companies exhibit better information gathering and analysis, human resource development, supplier and customer relations, and overall management practices. In specific countries, Swann et al. (1996) show adoption of ISO 9000 standards increases exports in England; Blind (2001) also find the positive impact in Sweden. In the international scope, Grajek (2004) studies the impact of ISO 9000 standards on bilateral exports among 101 countries during the period from 2001 to 2005. He finds both domestic and foreign ISO 9000 adoption benefits bilateral exports.

Critiques of these studies present different results. Temple and Urga (1997) argue the results in Swann et al. (1996) do not hold if variables to measure labor and capital are included in the model. Blind and Jungmittag (2002) find adoption of the standards in Germany has almost no effect on exports to France. In addition, Clougherty and Grajek (2008) study the exports from 52 OECD countries and report that the effect of the standards on these country exports is very marginal. Overall, country level studies do not provide consistent evidence whether adoption of ISO 9000 standards increases exports.

It is a costly process to apply for the quality standards. To pass the ISO 9000 audit, a firm needs an average of 6 to 18 months of preparation. According to Anderson and Sohal (1999), in the United States, the average certification cost for a middle-size enterprise (around 100 employees) is about $\$ 50,000$; it is about $\$ 300,000$ for a big-size enterprise (more than 100 employees). Dissanayaka et al. (2001) argue the adoption of ISO 9000 leads to more paperwork, increased time spent in management, and higher overall project cost. Therefore, it is important to understand, in what types of firms, ISO 9000 standards increase exports.

The studies on the impact of ISO 9000 standards using firm-level data are limited. Masakure et al (2009) uses the firm exports from 137 enterprises in Pakistan during the period from 2000 to 2004. They find ISO 9000 standards increases firm exports, especially for those who started exports recently. Martincus et al. (2010) study Argentina firm exports from 1998 to 2006. They find ISO 9000 standards not only increase exports but also increase the number of destination countries. Another study by Chen et al. (2008) uses the survey data from World Bank Technical Barriers to Trade Survey (2004). They find, in developing countries, compliance with the quality standards increases the total exports, as well as the number of export markets and products.

All these studies confirm the positive relation between obtaining the quality standards and export growth. There is no evidence, however, whether the impact of ISO 9000 standards on exports differ among industries and firm ownership structure.

\section{EMPIRICAL MODEL AND VARIABLE DEFINITION}

Following the literature, we use the difference-in-differences approach to study whether firms adopting ISO 9000 standards have increased exports than had they did not. In particular, we use this equation to denote the export 
difference: $\left(\operatorname{Export}_{i}^{1} \mid \operatorname{Cert}_{i}=1\right)$ - $\left(\right.$ Export $\left._{i}^{1} \mid \operatorname{Cert}_{i}=0\right)$. Cert $_{i}=1$ if a firm i gets the certification; otherwise, $\operatorname{Cert}_{i}=0 . \quad\left(\right.$ Export $_{i}^{1} \mid$ Cert $\left._{i}=1\right)$ and $\left(\right.$ Export $_{i}^{1} \mid$ Cert $\left._{i}=0\right)$ denote the exports from firm i in period 1 with and without obtaining the certification, respectively. At a certain point of time, a firm can either be certified or not. The above difference therefore is not observable. Furthermore, since the adoption of the quality standards is voluntary, the observed data may not be random. In this case, we cannot simply use the exports from non-certified firms to proxy for the exports from certified firms. That is,

$\left(\operatorname{Export}_{j}^{1} \mid \operatorname{Cert}_{j}=0\right) \neq\left(\right.$ Export $_{i}^{1} \mid$ Cert $\left._{i}=0\right)$, if firm $\mathrm{j}$ is not certified.

In order to control for the self-selection in applying for the quality standards, we employ the propensity score methodology proposed by Rosenbaum and Rubin (1983) and Heckman, LaLonde and Smith (1999). First, including all treated and control firms, we identify a set of variables $\left(\mathrm{X}_{\mathrm{i}}\right)$ in period 0 that are related with the probability of getting ISO 9000 certification in period 1 . We can consistently estimate $\operatorname{Pr}(\operatorname{Cert}=1 \mid X)=P(X)$, or the propensity score. After we control for the propensity of getting certified, the observed export can be independent from the decision of getting certified $\left(\operatorname{Export}_{i}^{1} ; \operatorname{Export}_{j}^{1}\right) \perp \operatorname{Cert}_{i, j} \mid X_{i, j}$, which avoids biased estimation.

Then, using a certain matching estimator, we find the matching firm (j) from the control sample who has the best matched $X_{j}$ with the treated firm $X_{i}$. There are different ways of getting matching estimators. The most commonly used approaches are the nearest neighbor matching (NNM) and kernel-based matching (KBM) methods (Heckman et al., 1997; Becker and Ichino, 2002). The NNM consists of matching each treated firm with the control firm that has the closest propensity score. The ATT is the average of all the differences of each pair of matched firms. The KBM finds each treated firm with a set of control firms. The ATT is the average of all the differences between treated firm and the weighted average of control firms, using weights that are inversely related to the distance between the propensity score of treated and control groups.

Through the matching process, the control firm is expected to have the same exports in period 1 with the treated firm(s) had it got ISO 9000 standards. In this case, we can use $\left(\operatorname{Export}_{j}^{1} \mid X_{j}, \operatorname{Cert}_{j}=0\right)$ to mimic $\left(\right.$ Export $_{i}^{1} \mid X_{i}$, Cert $\left._{i}=0\right) .^{7}$ The average treatment effect on treated, that is, ATT $=\left(\right.$ Export $_{i}^{1} \mid$ Cert $\left._{i}=1\right)$ $\left(\right.$ Export $_{i}^{1} \mid$ Cert $\left._{i}=0\right) \quad$ can be substituted by the difference between $\left(\right.$ Export $_{i}^{1} \mid$ Cert $\left._{i}=1\right)$ and $\left(\right.$ Export $_{j}^{1} \mid$ Cert $\left._{j}=0\right){ }^{8}$ Our main focus is whether this ATT is statistically positive.

In order to find the best matched firm(s), we need to determine what factors are related with the propensity to become certified. We control for the existing level of exports, measured by the natural log of the firm's exports lag one year (EXPORT_0). Successful previous exports indicate that a firm has established foreign sales channels and built up its market reputation. Adopting the costly standards, in this case, may not add additional value to the firm. On the other hand, existing exports also measure the firm size. Bigger firms benefit from smaller certification cost per unit of sales and thus are more willing to apply for the certification. Given these two contradictory effects,

\footnotetext{
7 In particular, to mimic the exports of getting certified in period 1 (Export ${ }_{i}^{1} \mid$ Cert $\left._{i}=1\right)$, the matched exports without certification $\left(\right.$ Export $_{j}^{1} \mid$ Cert $\left._{j}=0\right)$ can be calculated as $\sum_{j \in C^{0}} w_{i j}\left(\right.$ Export $_{j}^{1} \mid$ Cert $\left._{j}=0\right)$, where $\mathrm{C}^{0}$ is the set of neighbors with similar probability $P(X)$ of getting certified given the set of $\mathrm{X}_{\mathrm{i}} ; \quad w_{i j}=\frac{G_{i j}}{\sum_{j \in C^{0}} G_{i j}}$ is the weight of control firms' export in period 1 so that $\sum_{j \in C^{0}} w_{i j}=1 ; \mathrm{G}_{\mathrm{ij}}=\mathrm{G}\left(\left(\mathrm{X}_{\mathrm{i}}-\mathrm{X}_{\mathrm{j}}\right) / \mathrm{a}_{\mathrm{N} 0}\right)$ is a kernel that downweights distant observations from $X_{\mathrm{i}}$ and $a_{N_{0}}$ is a sequence of smoothing parameters with the property that $\lim _{N_{0} \rightarrow \infty} a_{N_{0}}=0$.

${ }^{8}$ Martincus et al. (2010) also use this methodology in studying the ISO 9000 certification effect in Argitina firms.
} 
we use other variables to measure firm size, including the natural log of total assets (SIZE), the average wages per employee (WAGE), and the number of product lines (PROD) (Martincus, 2010).

With the certification effect from the international quality standards, firms are exposed to more growth opportunities. Productivity decides whether the firm can take good advantage of these growth opportunities (Melitz, 2003). We use the industry value added over the number of employees to measure labor productivity (LP). Finley and Buntzman (1994) argue more mature firms have higher brand recognition in the market, which brings them more retaining customers and make it easy to penetrate new markets. Meanwhile, firms incorporated since long are more likely to have diversified products and benefit from economy of scope. Branstetter and Lardy (2006) find Chinese firms with foreign ownership easier to build up overseas network that boosts sales. Therefore, firm ages (AGE) and foreign shareholder dummy (FOREIGN) are included in the study.

\section{DATA AND SAMPLE SELECTION}

We start our sample collection from China Industry Business Performance Data. All national industrial enterprises and large non-national industrial enterprises are required to submit quarterly and annual performance data to local bureaus of statistics, who report to the China National Bureau of Statistics to compose the China Industry Business Performance Data. ${ }^{9}$ This dataset starts from 1998 and the most updated version covers firm performance until 2007. There are in total 550,000 different enterprises included in the report, which covers $89.5 \%$ of all Chinese industrial firms. The firm-level variables includes the firm name, industry, firm type, incorporation year, number of employees, assets, debts, revenue, net income, etc. This dataset is currently the largest and most comprehensive source of Chinese industrial firm-level performance.

Our sample period is from 2005 until 2007 because the firm level exports from China Industry Business Performance Data starts from 2005 while ISO9000 standards have a new version after 2008. Since Chinese exports are largely affected by governance policy, which can differ significantly across provinces, we focus on a specific province to avoid the regional policy differences. In particular, we choose Zhejiang Province, the third largest exporting province among the 32 provinces in China. ${ }^{10}$ Further, we require the firm has continuous records on the main variables. Our initial sample includes 10,076 firms.

We get the ISO9000 certification information from Certification and Accreditation Administration of the People's Republic of China. During the period from 2005 to 2007, there are 4,686 firms who get ISO9000 certification in 2005 and keep having it to 2007. There are 5,223 firms never got certification. We exclude 167 firms who got the certification in 2005 but did not keep it to 2007. Our final sample includes 9,909 firms.

Table 1 lists the descriptive statistics for main variables. "CERTI" equals one if a firm has ISO9000 certification in 2005; otherwise, zero. "EXPORT" is the volume of exports in 2007 (RMB mil). "EXPORT_0" is the volume of exports in 2005 (RMB mil). The variables listed below are all from China Industry Business Performance Data and are measured in year 2004. "PROD" is the natural log of number of product lines. "AGE" is the number of years of incorporation until year 2005. "SIZE" is the value of total assets (RMB mil). "FOREIGN" is a dummy variable of foreign shareholder's ownership. "WAGE" is the average wage per employee (RMB). "LP" is labor productivity measured as the industry value added over the number of employees. All continuous variables are winsorized at the $1 \%$ and $99 \%$ level.

\footnotetext{
${ }^{9}$ Large non-national industrial enterprises are those with annual operating income more than RMB 5 million (2010 Chinese Yuan).

${ }^{10}$ In 2011, the top three provinces of exports are Guangdong Province ( $\$ 531,900$ mil), Jiangsu Province $(\$ 312,600$ mil), and Zhejiang Province $(\$ 216,400 \mathrm{mil})$.

${ }^{11}$ We also use the natural log of total number of employees to measure firm size. The results do not change.
} 
Table 1: Descriptive Statistics

\begin{tabular}{lcrrrrr}
\hline Variable & $\mathbf{N}$ & Mean & $\mathbf{2 5 \%}$ & Median & $\mathbf{7 5 \%}$ & Std. Dev. \\
\hline CERTI & 9,909 & 0.47 & 0.00 & 1.00 & 1.00 & 0.50 \\
EXPORT & 9,909 & 55.91 & 7.48 & 17.86 & 44.45 & 283.84 \\
LN(EXPORT) & 9,909 & 2.94 & 2.14 & 2.94 & 3.82 & 1.40 \\
EXPORT_0 & 9,909 & 42.14 & 6.77 & 14.67 & 34.78 & 177.97 \\
LN(EXPORT_0) & 9,909 & 2.67 & 1.91 & 2.69 & 3.55 & 1.49 \\
PROD & 9,909 & 1.40 & 1.00 & 1.00 & 2.00 & 0.69 \\
AGE & 9,909 & 8.55 & 5.00 & 7.00 & 10.00 & 6.80 \\
SIZE & 9,909 & 79.51 & 8.01 & 17.68 & 48.22 & 383.02 \\
LN(SIZE) & 9,909 & 3.07 & 2.08 & 2.87 & 3.88 & 1.36 \\
FOREIGN & 9,909 & 0.15 & 0.00 & 0.00 & 0.00 & 0.36 \\
WAGE & 9,909 & 18.93 & 10.03 & 12.67 & 17.30 & 54.08 \\
LN(WAGE) & 9,909 & 2.58 & 2.31 & 2.54 & 2.85 & 0.73 \\
LP & 9,909 & 76.24 & 23.75 & 38.95 & 70.08 & 365.02 \\
\hline
\end{tabular}

Table 1 shows the basic statistics of the main variables. In our sample, $47 \%$ of the firms have the ISO 9000 certification in 2005. The average volume of exports in 2005 is 42.14 million RMB, and it increases to 55.91 million $\mathrm{RMB}$ in 2007 . Around $15 \%$ of the sample firms have foreign shareholders.

\section{EMPIRICAL RESULTS}

In this section, we report the empirical study evidence. First, we use the univariate tests to examine whether certified firms and non-certified firms are different in exports as well as ex-ante firm characteristics. In multivariate analysis, we use the propensity score methodology to control for the propensity of obtaining the certification. Then, we study the impact of ISO9000 certification by comparing the export growth in treated firm with that in control firms. Based on the whole sample evidence, we further examine whether the certification impact is different across industries and ownership structures.

\section{Univariate Analysis}

Table 2 compares the certified firms with non-certified firms in their exports as well as ex-ante firm characteristics. The data shows the average volume of exports in certified firms is significantly higher than that in non-certified firms in 2005. This difference expands from 19.50 RMB million to 31.19 RMB million in 2007. This observation suggests ISO 9000 standards may increase firm level exports.

Table 2: Univariate Tests - Certified vs. Non-certified Firms

\begin{tabular}{|c|c|c|c|c|c|c|}
\hline \multicolumn{4}{|c|}{ Mean Difference } & \multicolumn{3}{|c|}{ Median Difference } \\
\hline Variable & $\begin{array}{l}\text { Certified } \\
\text { (1) }\end{array}$ & $\begin{array}{c}\text { Non-certified } \\
\text { (2) }\end{array}$ & $\begin{array}{c}\text { Diff. } \\
(1)-(2)\end{array}$ & $\begin{array}{c}\text { Certified } \\
\text { (3) }\end{array}$ & $\begin{array}{c}\text { Non-certified } \\
\text { (4) }\end{array}$ & $\begin{array}{c}\text { Diff. } \\
(3)-(4)\end{array}$ \\
\hline EXPORT & 72.35 & 41.16 & $31.19^{* * * * *}$ & 25.28 & 13.60 & $11.68^{* \ldots * * 2}$ \\
\hline LN(EXPORT) & 3.22 & 2.70 & $0.52^{* * *}$ & 3.27 & 2.68 & $0.59^{\text {*** }}$ \\
\hline EXPORT_0 & 52.42 & 32.92 & $19.50^{* * * *}$ & 18.75 & $\begin{array}{r}2.00 \\
12.48\end{array}$ & $6.27^{* * * *}$ \\
\hline LN(EXPORT_0) & 2.80 & 2.54 & $0.26^{* * *}$ & 2.93 & 2.52 & $0.41^{* * * *}$ \\
\hline PROD & 1.46 & 1.36 & $0.10^{* * * *}$ & 1.00 & 1.00 & $0.00^{\text {**** }}$ \\
\hline AGE & 8.93 & 8.21 & $0.72^{* * * *}$ & 7.00 & 7.00 & $0.00^{* * * *}$ \\
\hline SIZE & 93.88 & 66.63 & $27.25^{\text {**** }}$ & 26.27 & 12.09 & $14.18^{* * *}$ \\
\hline LN(SIZE) & 3.44 & 2.73 & $0.71^{* * * *}$ & 3.27 & 2.49 & $0.78^{* * *}$ \\
\hline FOREIGN & 0.16 & 0.15 & $0.01^{* *}$ & 0.00 & 0.00 & $0.00^{* * *}$ \\
\hline WAGE & 17.72 & 20.02 & $-2.30^{* *}$ & 12.94 & 12.40 & $0.54^{* * * *}$ \\
\hline LN(WAGE) & 2.58 & 2.57 & 0.01 & 2.56 & 2.52 & $0.04^{* * * *}$ \\
\hline LP & 74.65 & 77.67 & -3.02 & 41.47 & 36.88 & $4.60^{\text {**** }}$ \\
\hline
\end{tabular}

When we compare other firm characteristics, we find certified firms and non-certified firms are different in many aspects. Certified firms tend to be larger and more mature. They have more diversified products and higher labor productivity, and are more likely to have investment from foreign shareholders. Compared with non-certified 
firms, the certified firms have a lower average wage level but a higher median wage level, indicating the wage distribution is less skewed to the high payment.

Overall, these observations suggest we need to control for ex-ante firm characteristics to study the impact of ISO 9000 on export growth since these factors may contribute to the export growth difference between certified and non-certified firms.

\section{Multivariate Analysis - Whole Sample}

First, we use the Logit model to test the probability of applying for the quality certification. The results are reported in Table 3. T-value is reported in parentheses. ${ }^{* * *},{ }^{* *}$ and ${ }^{*}$ indicate statistical significance at $1 \%, 5 \%$, and $10 \%$, respectively.

Table 3: Logit Model Regression of Obtaining ISO 9000 Standards Probability

\begin{tabular}{lcccc}
\hline Variable & $\mathbf{( 1 )}$ & $\mathbf{( 2 )}$ & $\mathbf{( 3 )}$ & $\mathbf{( 4 )}$ \\
\hline LN(EXPORT_0) & $-0.07^{* * * *}$ & $-0.07^{* * *}$ & $-0.07^{* * *}$ & $-0.07^{* * *}$ \\
& $(-4.48)$ & $(-4.24)$ & $(-4.14)$ & $(-4.13)$ \\
LN(SIZE) & $0.45^{* * * *}$ & $0.45^{* * *}$ & $0.45^{* * * *}$ & $0.45^{* * * *}$ \\
& $(24.14)$ & $(23.64)$ & $(23.36)$ & $(23.40)$ \\
PROD & & $0.13^{* * *}$ & $0.13^{* * * *}$ & $0.13^{* * * *}$ \\
& & $(4.22)$ & $(4.22)$ & $(4.26)$ \\
LN(WAGE) & $0.05^{*}$ & $0.05^{*}$ & $0.07^{* *}$ \\
& & $(1.73)$ & $(1.86)$ & $(2.29)$ \\
FOREIGN & & $-0.10^{*}$ & $-0.11^{*}$ \\
& & & $(-1.75)$ & $(-1.78)$ \\
AGE & & -0.0038 & -0.0038 \\
& & & $(-1.14)$ & $(-1.19)$ \\
LP & & & -0.0001 \\
& & & & $(-1.34)$ \\
Constant & & -1.59 & -1.63 \\
$\mathrm{~N}$ & -1.30 & 9,909 & -1.59 & 9,909 \\
\hline
\end{tabular}

The dependent variable is a binary variable CERTI, which equals one if a firm has ISO9000 certification in 2005; otherwise, zero. All the independent variables are measured at the firm level in 2004. Model (1) supports the argument that firms with already established sales channels may not have strong incentive to apply for the quality standards. Larger firms are more likely to do so because of lower average application cost. In the next three models, we include additional control variables, the results do not change. Firm diversification (PROD) is positively related with certification probability because diversified products and markets allow the firm to benefit more from the certification. Firms with higher production continuity (measured by wage and productivity) are more likely to get certification.

The relation between foreign-invested firms and certification may be more complicated. On the one hand, foreign-invested firms are more likely to get certification since their products are usually exported to foreign markets. On the other hand, because of existing sales channels, foreign-invested firms usually bear lower transaction costs in international trades and thus have lower incentive to get certification. The result shows that foreign firms have less intention to obtain the quality certification.

Based on the certification probability estimates, we then match each certified firm with the most similar noncertified firm (nearest neighbor matching) or with noncertified firms with the weighted defined by the difference between their propensity scores and that of the certified firm (kernel matching). To further check whether the nearest neighbor and kernel estimation processes are qualified, we use the balancing test. It is to check whether the estimation can balance the distribution of the relevant variables in both the certified and the control groups. If these two groups are significantly different in relevant variables, the matching is not qualified and the kernel estimation will not be valid. According to Smith and Todd (2005) and Martincus et al. (2010), we compute the standard bias (SB) as follows: 


$$
S B=100 * \frac{\left(\overline{X^{t}}-\overline{X^{c}}\right)}{\sqrt{0.5^{*}\left[V^{t}(X)+V^{c}(X)\right]}}
$$

where $\overline{X^{t}}$ and $V^{t}$ are the mean and variance in the treated group, while $\overline{X^{c}}$ and $V^{c}$ are the mean and variance in the control group. The smaller the standard bias, the more balanced or similar the treatment and comparison groups will be in terms of the variable under consideration (Rosenbaum and Rubin, 1985). Following Girma (2007), we consider an absolute SB value of 20 suggesting a qualified matching; otherwise, the matching procedure is not reliable.

Table 4: Indicators Of Matching Quality - Standardized Bias

\begin{tabular}{lcccc}
\hline Panel A: Nearest Neighbor Matching & Treated & Control & T-value & $\mid$ SB $\mid$ \\
\hline LN(EXPORT_0) & 2.80 & 2.75 & 1.45 & 3.20 \\
LN(SIZE) & 3.44 & 3.44 & 0.15 & 0.30 \\
PROD & 1.46 & 1.45 & 0.14 & 0.30 \\
LN(WAGE) & 2.58 & 2.56 & 1.20 & 2.50 \\
FOREIGN & 0.16 & 0.16 & -0.46 & -1.00 \\
AGE & 8.93 & 8.76 & 1.16 & 2.40 \\
LP & 74.65 & 75.10 & -0.08 & -0.1 \\
\hline Panel B: Kernel Matching & Treated & Control & T-value & $\mid$ SB| $\mid$ \\
\hline LN(EXPORT_0) & 2.80 & 2.74 & 1.65 & 3.70 \\
LN(SIZE) & 3.44 & 3.41 & 0.91 & 1.90 \\
PROD & 1.46 & 1.45 & 0.62 & 1.30 \\
LN(WAGE) & 2.58 & 2.56 & 1.00 & 2.10 \\
FOREIGN & 0.16 & 0.16 & -0.39 & -0.80 \\
AGE & 8.93 & 8.69 & 1.64 & 3.40 \\
LP & 74.65 & 77.91 & -0.51 & -0.90 \\
\hline
\end{tabular}

Table 4 reports the mean of each relevant variable in treated and control groups. We conduct a two-sample T-test and calculate the absolute standardized bias to check whether there are significant differences in the means. In particular, Panel A shows the comparison between treated firms and the most similar control firms, and the Panel B shows that between treated firms and the whole control group. The two sample T-tests suggest that all mean differences are not statistically different from zero. The absolute standard biases are all much less than 20 , indicating the matching procedure of high quality. Using these match procedures, we can then examine whether ISO 9000 standards are associated with significant export growth.

Table 5: The Impact Of ISO9000 Standards On Future Exports

\begin{tabular}{lcc}
\hline & Kernel Matching & Nearest Neighbor Matching \\
\hline LN(EXPORT) & $0.30^{* * * *}$ & $0.28^{* * * *}$ \\
T-statistics & 9.86 & 9.02 \\
Common support imposed & Yes & Yes \\
Balancing property satisfied & Yes & Yes \\
Treated & 4,686 & 4,686 \\
Controls & 5,223 & 5,223 \\
\hline
\end{tabular}

The effect of certification on exports is listed in Table 5. Table 5 shows, in the whole sample, the ISO 9000 certification has a positive and significant effect on firm future exports after controlling for the probability of obtaining the certification. The results are robust with both matching methodologies. After certification, on average, the firm exports increase more than $\mathrm{RMB} 1,336,400 .{ }^{12}$ This finding is consistent with existing literature that the international quality standards facilitate export growth (Masakure et al., 2009; Martincus, et al., 2010).

\footnotetext{
${ }^{12} \mathrm{LN}($ EXPORT) increases an average of 0.29. Converting it to export growth in million RMB, we get RMB 1,336,400. 


\section{Across Industry Analysis - High Tech vs. Low Tech}

Previous empirical studies argue the quality certification has diverse impact on exports across industries. The model of Garella and Petrakis (2008) shows, when consumers have less information about product quality, the minimum quality standards (MQS) more likely increases perceived product quality and thus willingness to pay for the goods. Therefore, the use of MQS policies has bigger influence on exports in markets with more severe information asymmetry. Moenius (2006) argues the processing technology matters for the effect of quality certification. When the processing technology is more complicated, it is more costly to get product information. Certification by international standards, in this case, plays a more important role in signaling product quality to increase exports. According to these arguments, we expect that high technology firms, because of their more advanced technology and thus more costly product information, should benefit more from the ISO 9000 standards certification.

According to OECD ISIC REV. 3 Technology Intensity Definition, we categorize the 9,909 sample firms into high-technology industries, medium-high-technology industries, medium-low-technology industries, and lowtechnology industries. Similar to the previous procedure, we first use the kernel matching to control for the probability of obtaining the quality certification and then test the impact of the certification on exports. ${ }^{13}$

Table 6: Certification Effects By Industries

\begin{tabular}{|c|c|c|c|c|}
\hline \\
\hline Panel A & Low Tech & Medium-Low Tech & Medium-High Tech & High Tech \\
\hline LN(EXPORT) & $0.37^{* * * *}$ & $0.24^{* * * *}$ & $0.19^{* * * *}$ & 0.20 \\
\hline T-statistics & 8.42 & 3.07 & 3.40 & 1.58 \\
\hline Common support imposed & Yes & Yes & Yes & Yes \\
\hline Balancing property satisfied & Yes & Yes & Yes & Yes \\
\hline Treated & 1,655 & 779 & 1,858 & 394 \\
\hline Controls & 3,096 & 715 & 1,153 & 259 \\
\hline Panel B & \multicolumn{2}{|c|}{ Low Tech } & \multicolumn{2}{|c|}{ Medium-Low Tech } \\
\hline & $(1)$ & $(2)$ & (3) & (4) \\
\hline LN(EXPORT) & $0.35^{* * * *}$ & $0.20^{* * *}$ & 0.14 & $0.28^{* * * *}$ \\
\hline T-statistics & 6.29 & 2.40 & 1.16 & 2.66 \\
\hline Common support imposed & Yes & Yes & Yes & Yes \\
\hline Balancing property satisfied & Yes & Yes & Yes & Yes \\
\hline Treated & 907 & 515 & 316 & 391 \\
\hline \multirow[t]{3}{*}{ Controls } & 2,218 & 631 & 311 & 363 \\
\hline & \multicolumn{2}{|c|}{ Medium-High Tech } & \multicolumn{2}{|c|}{ High Tech } \\
\hline & (5) & $(6)$ & (7) & (8) \\
\hline LN(EXPORT) & 0.14 & $0.26^{* * *}$ & 0.07 & -0.02 \\
\hline T-statistics & 1.82 & 2.35 & 0.29 & -0.12 \\
\hline Common support imposed & Yes & Yes & Yes & Yes \\
\hline Balancing property satisfied & Yes & Yes & Yes & Yes \\
\hline Treated & 921 & 565 & 213 & 127 \\
\hline Controls & 613 & 302 & 82 & 101 \\
\hline
\end{tabular}

Panel A in Table 6 shows that ISO9000 certification increases exports only in non-high-tech industries. The exports increase the most in low tech industries. On average, exports from certified low-technology firms are RMB 1.45 million more than those from uncertified low-technology firms (p-value less than 0.01).

To provide a detailed description of the quality standards' impact on exports, we study the two largest subindustries in each industry category. ${ }^{14}$ Column (1) in Panel B of Table 6 is "Textiles, textile products, leather and footwear", column (2) is "Manufacturing, Recycling", column (3) is "Basic metals and fabricated metal products", column (4) is "Rubber and plastics products", column (5) is "Railroad equipment and transport equipment", column (6) is "Electrical machinery and apparatus", column (7) is "Office, accounting and computing machinery", and

\footnotetext{
${ }^{13}$ The results using the nearest neighbor matching are very similar. To save space, we only report the results with Kernel matching in the following tables.

${ }^{14}$ Appendix $\mathrm{C}$ shows the sample distribution in each sub-industries.
} 
column (8) is "Medical, precision and optical instruments". The data confirms that only in low-technology subindustries and the "rubber and plastic products" in medium-low-technology industries, ISO 9000 standards certification increases exports (both p-values less than 0.01). Overall, the cross industry analysis shows the quality standards only positively affects exports in industries of low technology.

This observation is to the contrary of our expectation. We attribute it to the developing countries' specific business environment. Clougherty and Grajek (2008) argue the reason that the adoption of ISO 9000 standards benefits developing countries more than it does to developed countries is that developing countries face particularly high information asymmetries and transaction costs in exports. ISO 9000 certification can better serve as the quality assurance that helps to build up the "business-to-business contractual relations" (Conti, 1999).

In developing countries, high-tech industries usually may be able to signal their product quality through other channels, such as patent grants. Low-technology industries, on the other hand, are harder to distinguish their products from each other. Since ISO 9000 certification ensures that an organization has a documented quality management system, it can signal the supplier's capability to deliver quality products, which decreases information asymmetry and transaction cost in low-technology product trades. Therefore, we find in our sample low technology firms benefit more from quality certification than high technology firms.

\section{Ownership Structure Analysis - SOE vs. Non-SOE}

Chinese SOEs have gone through significant reforms and restructuring. However, many studies find SOEs are still not as competitive as private enterprises. Mak (2008) study the time-series operating performance of China's state-owned hotels (SOHs). He argues that SOHs' focus on short-term rather than long-term profits decreases the overall performance. Pyke et al. (2002) compares the level of technology between enterprises of different ownership in China. They find the level of technology in SOEs significantly lags behind that in foreign-owned or joint enterprises. Government ownership and its related problems, such as complicated ownership, bureaucratic structure and control can also jeopardize the positive effect of obtaining ISO 9000 standards. We, therefore, repeat the previous regressions on subsamples of SOEs and non-SOEs.

Table 7: Certification Effects By Ownership Structure

\begin{tabular}{lcc}
\hline Panel A & State-Owned & Non-State-Owned \\
\hline LN(EXPORT) & 0.37 & $0.29^{* * * *}$ \\
T-statistics & 1.04 & 9.67 \\
Common support imposed & Yes & Yes \\
Balancing property satisfied & Yes & Yes \\
Treated & 63 & 4,623 \\
Controls & 57 & 5,166 \\
\hline Panel B & State-Share & Non-State-Share \\
\hline LN(EXPORT) & $0.29^{* * * * *}$ & $0.29^{* * * *}$ \\
\hline T-statistics & 2.94 & 9.32 \\
\hline Common support imposed & Yes & Yes \\
\hline Balancing property satisfied & Yes & Yes \\
\hline Treated & 628 & 4058 \\
\hline Controls & 423 & 4800 \\
\hline
\end{tabular}

Consistent with our expectation, Panel A in Table 7 shows ISO 9000 standards adoption has a significant impact only in non-SOEs. On average, non-SOE exports increase RMB 18.32 million after obtaining ISO 9000 standards (p-value less than 0.01). SOEs, however, are not affected by the certification effect of ISO 9000 standards. When we compare firms with state ownership with those without state ownership, the results in Panel B do not show difference in the impact of ISO 9000 on export growth. This evidence further support the argument that only significant state government ownership affects the effect of the quality standards.

In our sample, $53 \%$ of SOEs adopt the quality standards while only $47 \%$ of non-SOEs do so. This high tendency to adopt the non-beneficial international quality standards suggests, because of the subsidy from state governments, SOEs are not sensitive to the cost burden of obtaining the quality certification. Meanwhile, not 
pursuing the profit maximization (Bai et al., 1997), SOEs may apply for the quality standards just to comply with government. On the other hand, non-SOEs or those firms that do not have significant state government ownership have a better management mechanism that motivates the best use of the certification by the ISO 9000 standards.

\section{CONCLUSION}

There are not many existing studies of the impact of international standards on firm-level performance, especially in developing countries. Our study is the first to examine whether the adoption of ISO 9000 standards increases Chinese firm exports. To address the endogeneity issue in obtaining the standards, we use the kernel matching and nearest neighbor matching methodologies to compare the average impact of certification between treated and control groups. Our results show that obtaining ISO 9000 certification significantly increases exports with an average of more than RMB 1.33 million.

Furthermore, we compare the impact of quality standards on exports among industries and firms with different ownership. Our results show that low-technology firms and non-SOE firms increase exports more than high-technology and SOE's. These findings provide entrepreneurs and the Chinese government with guidance for obtaining ISO 9000 certification. Overall, our research provides new firm-level evidence that certification by international standards has positive impact on exports.

\section{AUTHORS' INFORMATION}

Ying Sun is an Assistant Professor of Economics at College of Economics and Management at China JiLiang University. Dr. Sun holds a PhD in Macroeconomics from Zhejiang University. Her research interests include international trade and trade policy analysis. Dr. Sun teaches international settlements and international economics courses. Dr. Ying Sun, College of Economics and Management, China JiLiang University, Xueyuan Street, Xiasha Higher Education District, Hangzhou Zhejiang, 310018 China. E-mail: sunying@cjlu.edu.cn.

Wenjing Ouyang is an Assistant Professor of Finance at the Eberhardt School of Business at the University of the Pacific. Dr. Ouyang holds a PhD in Finance from Drexel University. Her research interests include mergers and acquisitions, information asymmetry, and international finance. Her teaching interests include corporate finance and investment. Dr. Wenjing Ouyang, Eberhardt School of Business, University of the Pacific, 3601 Pacific Ave, Stockton, CA 95211 USA. E-mail: wouyang@pacific.edu.

\section{ACKNOWLEDGEMENTS}

This research is funded by National Natural Science Foundation of China (Project No. 71103168). We thank all panel participants at the 2013 Las Vegas International Academic Conference. All errors are our own.

\section{REFERENCES}

1. Amiti, M., \& Freund, C. (2010). The anatomy of China's export growth. In China's growing role in world trade (pp. 35-56). University of Chicago Press.

2. Anderson, S. W., Daly, J. D., \& Johnson, M. F. (1999). Why firms seek ISO 9000 certification: regulatory compliance or competitive advantage?. Production and Operations Management, 8(1), 28-43.

3. Bai, C. E., Li, D. D., \& Wang, Y. (1997). Enterprise productivity and efficiency: When is up really down?. Journal of Comparative Economics, 24(3), 265-280.

4. Becker, S. O., \& Ichino, A. (2002). Estimation of average treatment effects based on propensity scores. The Stata Journal, 2(4), 358-377.

5. Bernard, A. B., Jensen, J. B., Eaton, J., \& Kortum, S. (2003). Plants and Productivity in International Trade. American Economic Review, 93(4), 1268-1290.

6. Blind, K. (2001). The impacts of innovations and standards on trade of measurement and testing products: empirical results of Switzerland's bilateral trade flows with Germany, France and the UK. Information Economics and Policy, 13(4), 439-460.

7. Blind, K., \& Jungmittag, A. (2002). The Impacts of Innovation and Standards on German-France Trade Flows. Fraunhofer Institute for Systems and Innovation Research, Karlsruhe. 
8. Branstetter, L., \& Lardy, N. (2006). China's embrace of globalization (No. w12373). National Bureau of Economic Research.

9. Chen, M.X., Wilson, J. S., \& Ostuki, T. (2008) Standards and Export Decisions: Firm-Level Evidence from Developing Countries. Journal of International Trade and Economic Development, 17(4), 501-523.

10. Clougherty, J.A. \& Grajek, M. (2008). The Impact of ISO 9000 Diffusion on Trade and FDI: A New Institutional Analysis. Journal of International Business Studies, 39 (4), 613-633.

11. Conti, T. (1999). Vision 2000: Positioning the New ISO 9000 Standards with Respect to Total Quality Management Models. Total Quality Management, 10(4/5), 454-464.

12. Dissanayaka, S.M., Kumarsawamy, M.M., Karim, K., \& Marosszeky, M. (2001). Evaluating Outcomes from ISO 9000-certified Quality Systems of Hong Kong Constructors. Total Quality Management, 12(1), 29-40.

13. Finley, L., \& Buntzman, G.F. (1994). What does affect company performance? Arkansas Business and Economic Review, 27 (2), 1-15.

14. Garella, P.G., \& Petrakis, E. (2008). Minimum quality standards and consumers' information. Economic Theory, 36, 283-302.

15. Girma, S., \& Görg, H. (2007). Evaluating the foreign ownership wage premium using a difference-in-differences matching approach. Journal of International Economics, 72(1), 97-112.

16. Grajek, M. (2004). Diffusion of ISO 9000 Standards and International Trade. Discussion Papers, No. SP II 200416, Wissenschaftszentrum, Berlin.

17. Heckman, J., Ichimura, I., \& Todd, P. (1997). Matching as an econometric evaluation estimator: evidence from evaluating a job training programme. The Review of Economic Studies, 64(4), 605-654.

18. Heckman, J. J., LaLonde, R. J., \& Smith, J. A. (1999). The economics and econometrics of active labor market programs. Handbook of Labor Economics, 3, 1865-2097.

19. Jefferson, G. H., Rawski, T. G., \& Zheng, Y. (1994). Productivity change in Chinese industry: a comment. China Economic Review, 5(2), 235-241.

20. Lo, C. K., Yeung, A. C., \& Cheng, T. E. (2009). Impact of ISO 9000 on time-based performance: an event study. International Journal of Humanities and Social Science, 1, 35-40.

21. Martincus, C. V., Castresanao, S., \& Castagnin, T. (2010). ISO standards: a certificate to expand exports? Firmlevel evidence from Argentina. Review of International Economics, 18(5), 896-912.

22. Masakure, O., Henson, S., \& Cranfield, J. (2009). Standards and export performance in developing countries: evidence from Pakistan. The Journal of International Trade \& Economic Development, 18(3), 395-419.

23. Melitz, M.J. (2003). The Impact of Trade on Intra-Industry Reallocations and Aggregate Industry Productivity. Econometrica, 71, 1695-1725.

24. Moenius, J. (2006). The good, the bad and the ambiguous: standards and trade in agricultural products. IATRC Summer Symposium, 5, 28-30.

25. Pyke D., Farley, J., \& Robb, D. (2002). Manufacturing technology and operations in China: a survey of stateowned enterprises, private firms, joint ventures and wholly-owned foreign subsidiaries. European Management Journal, 20(4), 356-375.

26. Rao, S.S., Ragu-Nathan, T.S., \& Solis, L.E. (1997). Does ISO 9000 have an effect on quality management practices? an international empirical study. Total Quality Management, 8(6), 335-346.

27. Rodrik, D. (2006). What is so special about China's exports?. China \& World Economy, 14(5), 1-19.

28. Rosenbaum, P., \& Rubin, D. (1983). The Central Role of The Propensity in Observational Studies For Causal Effects. Biometrika, 70(1), 41-55.

29. Smith, J., \& Todd, P. (2005). Rejoinder. Journal of Econometrics, 125, 365-375.

30. Swann, G.M.P., Temple, P., \& Shurmer, M. (1996). Standards and trade performance: the British experience. Economic Journal, 106, 1297-1313.

31. Temple, P., \& Urga, G. (1997). The competitiveness of UK manufacturing: evidence from imports. Oxford Economic Papers, 49 (2), 207-227.

32. Uzumeri, M. V. (1997). ISO 9000 and other metastandards: principles for management practice?, Academy of Management Executive, 11(1), 21-36.

33. Xu, B., \& Lu, J. (2009). Foreign direct investment, processing trade, and the sophistication of China's exports. China Economic Review, 20, 425-439.

34. Yue, C., \& Hua, P. (2002). Does comparative advantage explains export patterns in China?. China Economic Review. 13, 276-296. 


\section{APPENDIX A}

The Number of ISO 9000 Certificates in China $(1993$ - 2011)

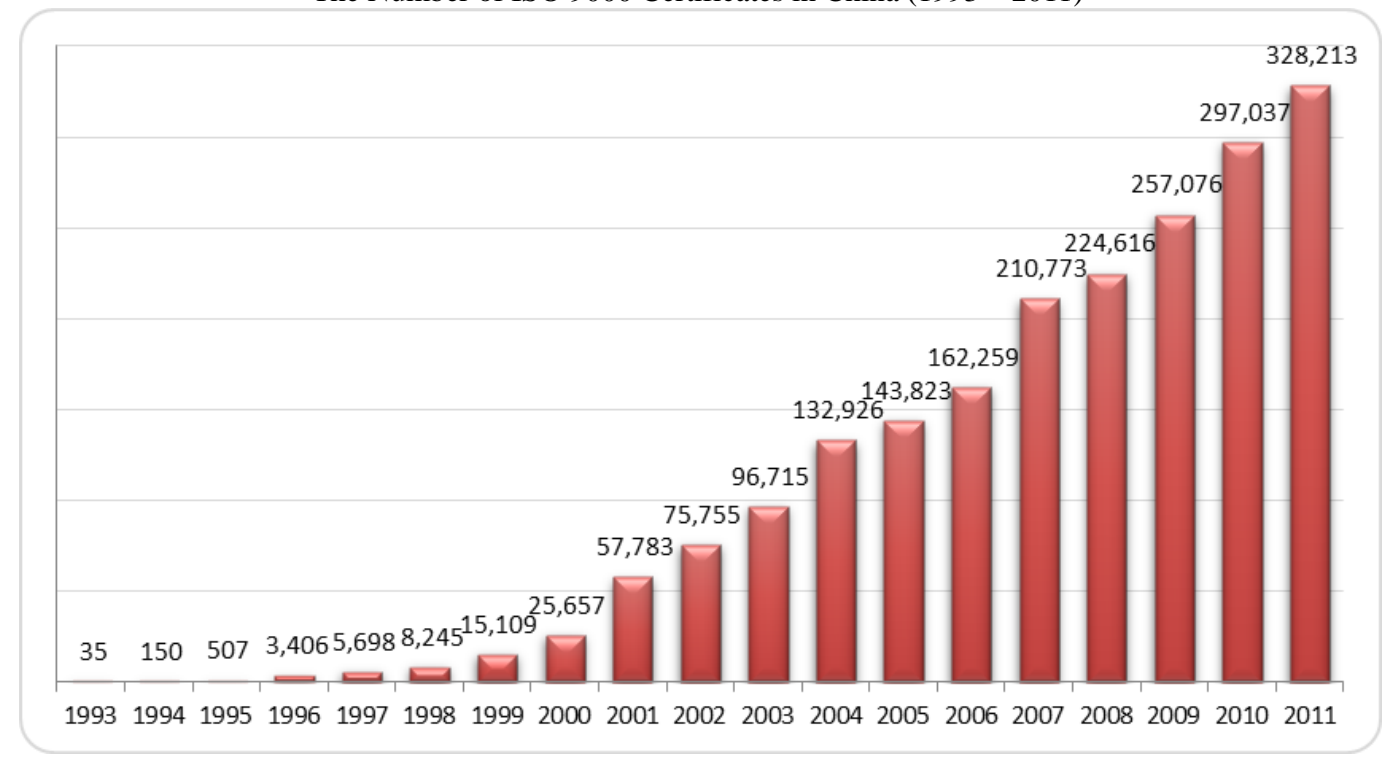

\section{APPENDIX B}

Top 10 Countries with ISO 9000 Certificates in 2011

The following table shows the top 10 countries in the world ranked by their possessed number of ISO 9000 certificates in 2011 . The percentage of their owned number of certificates is also reported.

\begin{tabular}{|r|c|c|c|}
\hline Rank & Country & \# of certificates & \% of top 10 total \\
\hline 1 & CHINA & 328,213 & $40.14 \%$ \\
\hline 2 & ITALY & 171,947 & $21.03 \%$ \\
\hline 3 & JAPAN & 56,912 & $6.96 \%$ \\
\hline 4 & SPAIN & 53,057 & $6.49 \%$ \\
\hline 5 & GERMANY & 49,540 & $6.06 \%$ \\
\hline 6 & UNITED KINGDOM & 43,564 & $5.33 \%$ \\
\hline 7 & INDIA & 29,574 & $3.62 \%$ \\
\hline 8 & FRANCE & 29,215 & $3.57 \%$ \\
\hline 10 & BRAZIL & 28,325 & $3.46 \%$ \\
\hline Top 10 Total & REPUBLIC OF KOREA & 27,284 & $3.34 \%$ \\
\hline
\end{tabular}




\section{APPENDIX C}

Number of Sample Firms by Industry

\begin{tabular}{lcc}
\hline Industry & \# of firms & percentage \\
\hline Low-technology industries & 3,125 & $31.54 \%$ \\
\hline Textiles, textile products, leather and footwear & 1,146 & $11.57 \%$ \\
Manufacturing, recycling & 353 & $3.56 \%$ \\
Food products, beverages and tobacco & 127 & $1.28 \%$ \\
Wood, pulp, paper, paper products, printing and publishing & & \\
\hline Medium-low-technology industries & 754 & $7.61 \%$ \\
\hline Basic metals and fabricated metal products & 627 & $6.33 \%$ \\
Rubber and plastics products & 108 & $1.09 \%$ \\
Other non-metallic mineral products & 5 & $0.05 \%$ \\
Coke, refined petroleum products and nuclear fuel & & \\
\hline Medium-high-technology industries & 1,534 & 867 \\
\hline Railroad equipment and transport equipment & 332 & $8.75 \%$ \\
Electrical machinery and apparatus & 278 & $3.35 \%$ \\
Chemicals excluding pharmaceuticals & & $2.81 \%$ \\
Machinery and equipment & 295 \\
\hline High-technology industries & 228 \\
\hline Office, accounting and computing machinery & 130 \\
Medical, precision and optical instruments & 9,909 \\
Pharmaceuticals & $2.98 \%$ \\
\hline Total & $2.30 \%$ \\
\hline
\end{tabular}

